\title{
EDUCAÇÃO: MATRIZ DE TODO PROJETO FORMATIVO
}

\section{Beatriz Santos Pontes}

Tomando como referência que a essência humana radica-se no "ir-se dando", como concretização de suas potencialidades e capacidades, é importante ressaltar que o homem, ao longo de sua existência, enfrenta obstáculos e desafios presentes na sua práxis, entendida como unidade indissolúvel entre ação e reflexão com vistas a uma reação às suas necessidades e carências. Como ser consciente, o homem (e só ele) é capaz de tomar distância frente ao mundo, de apropriar-se dele como objeto de sua compreensão; sendo assim, as relações estabelecidas entre homem-natureza (produto do trabalho) e homem-homem (relações dialógicas que levam à união) estão impregnadas pela busca constante de equilíbrio entre conhecimento e realização humana.

Atualmente, o que se evidencia é um grande "atropelamento" dos talentos, aptidões e habilidades do sujeito, sobretudo no que se refere aos portadores de necessidades educativas especiais. Sempre existiu uma grande controvérsia com relação à educabilidade desta camada populacional, uma vez que o despreparo dos profissionais e o estigma criado sobre estes sujeitos é bastante latente. GOFFMAN ( $1988: 11)$ coloca que:

A sociedade estabelece os meios de categorizar as pessoas e o total de atributos considerados como comuns e naturais para os membros de cada uma dessas categorias. Os ambientes sociais estabelecem as categorias de pessoas que têm probabilidade de serem neles encontradas. As rotinas de relação social em ambientes estabelecidos nos permitem um relacionamento com "outras pessoas" previstas sem atenção ou reflexão particular (...) quando um estranho nos é apresentado, os primeiros aspectos nos permitem prever a sua categoria e os seus atributos, a sua "identidade social" (...).

A partir do autor supracitado, pode-se inferir que o desafio maior da educação é adotar uma proposta pedagógica inspirada na globalidade da natureza humana. Traçar estratégias educacionais condizentes com a realidade apresentada não se limita à descrição de patologias, mas procede rumo a um itinerário formativo, com vistas à realização do sujeito nas diferentes áreas do conhecimento.

Há a necessidade de que o tempo de educação seja um tempo de crescimento pessoal, um tempo significativo de preparo para a vida, um tempo de senso de cidadania, um tempo de sensibilidade ecológica para sobreviver no planeta. Certamente, há a necessidade de se respeitar as diferenças, possibilitando a cada sujeito desenvolver-se de acordo com suas possibilidades e não desenvolvê-las em função daquilo que os outros desejam que ele seja.

Admite-se que o entendimento das necessidades individuais é bastante complexo. 
Estas, principalmente no que concerne aos portadores de necessidades educativas especiais, não foram determinadas em toda sua extensão, e muito menos chegou-se a resultados operacionalizáveis, o que torna a ação pedagógica uma arte, e porque não dizer, toda ela especial. Para lidar com as diferenças individuais, isto é, com a relação envolvida no processo ensinoaprendizagem, o educador deverá não só se expressar adequadamente, porque a ele cabe a tarefa de ensinar a fazer com que o outro aprenda, mas também se envolver não só com o ato de mudar, mas com o ato que antecedea mudança, o que só pode ser percebido através da escuta, escuta do que não é transparente e exige extrema sensibilidade

Sendo assim, o estudo do processo de aquisição e construção do conhecimento, sua natureza, caracteres e suas condições representam sem dúvida um fator de extrema importância para o entendimento da aprendizagem cognitiva nos contextos de instrução nos quais normalmente se produz. Explicar os mecanismos que envolvem o processo de aprendizagem é esclarecer a maneira pela qual o ser humano se desenvolve, toma conhecimento do mundo em que vive, organiza sua conduta e se ajusta ao meio físico social. É pela aprendizagem que o homem se afirma como ser racional, forma sua personalidade e se prepara para o papel que Ihe cabe no seio da sociedade.

Em nossas escolas, geralmente é levado em conta o desejo da escola (dona do saber) e é ignorado o desejo de conhecer do aluno, ocasionando assim, o fracasso escolar e até mesmo pedagógico.

O desejo do conhecer é muitas vezes ignorado pelos professores, porque o desejo supõe transformar a realidade e destruir o poder existente, automaticamente gerando insegurança por parte de quem o tem. Cabe salientar que este processo de transformação, a partir do desejo do conhecer o possível ou impossível, é muito longo e lento.

Muitos professores não conseguem ver seus alunos como sujeitos pensantesdesejantes, porque eles mesmos ignoram a respeito do seu modo de ensinar, conseqüentemente não podendo entender como ocorre a aprendizagem de seus alunos.

É preciso que a escola trabalhe com o desejo de conhecer o possível e o impossível do aluno, e para isso precisa de autoria neste conhecimento, ou seja, precisa fazer com que este sujeito ou professor aprenda, produza algo da e na realidade.

Muitas explicações da nossa realidade advém dos mitos surgidos ao longo da história da humanidade. Por exemplo, o aluno não aprendeu, porque não quis. $\mathrm{E}$ com essas palavras do professor, o aluno, imobilizado frente ao que não sabe lidar com suas palavras, também colabora para que o aprendizado não ocorra, transformando em mandato impedidor o seu próprio desejo. O conflito ocorre, segundo as afirmações de MENDES (1999:17): 
aprender.Elas vão, porque têm que aprender, mas, muitas vezes, nem sabem para que servirá essa aprendizagem.Além disso, muitas vezes aprender, significa diferenciar-se de seu grupo familiar em um processo de desindentificação que pode ser doloroso.

Enfim, o desejo de conhecer (possível) e o conhecer do desejo (impossível), sempre partirá do conhecimento do outro e de diferentes saberes para construir o próprio saber, mas precisa ser desvencilhado de alguns mandatos místicos de quem ensina e de quem aprende, e ao aluno deverá ser dada possibilidade de poder pensar com autonomia para uma possível autoria.

Dentro desta perspectiva, NOVAES (1992:21) é oportuna quando aponta que:

O verdadeiro homem, em cada um de nós, está sempre às espreitas, esperando a oportunidade de ser mais... Em cada pessoa, indistintamente, repousam potencialidades inexauríveis de aperfeiçoamento...Falta-nos, não raro a coragem de ser... Feliz de quem se deixa envolver pelo poder místico da realização pessoal.

\section{BIBLIOGRAFIA}

GOFFMAN, E. Estigma: notas sobre a manipulação da identidade

deteriorada. Trad. Márcia B. de M. L. Nunes. RJ: Guanabara, 1988, $4^{\mathrm{a} e d}$.

MENDES, G. O desejo de conhecer e o conhecer do desejo. Porto Alegre: Artes Médicas, 1999.

NOVAES, M. H. Psicologia da educação e prática profissional. Petrópolis: Vozes, 1992. 